\title{
Spatial distribution of bacterioplankton biomass and production in the marginal ice-edge zone of the Weddell-Scotia Sea during austral winter
}

\author{
Calvin W. Mordy*, David M. Penny**, Cornelius W. Sullivan*** \\ Hancock Institute for Marine Studies, University of Southern Califonia, Los Angeles, California 90089-0373, USA
}

\begin{abstract}
Recent investigations in the marginal ice-edge zone (MIZ) of the western Weddell and Scotia Seas revealed similar distributions of primary and microbial production in spring and autumn. Yet, little is known about the distributions of bacterial biomass and production in winter, and how these distributions may be influenced by local physical oceanographic features or interrelated to other chemical and biological distributions in the MlZ. To help elucidate the ecological and biogeochemical significance of bacterial production in winter, we examined the distributions of bacterial biomass and production in the MIZ of the Weddell-Scotia Sea in austral winter 1988 as part of the Antarctic Marine Ecosystem Research at the Ice-edge Zone (AMERIEZ) program. Measurements were made along 3 rapid transects providing a synoptic view of the MIZ. Transects were oriented normal to the ice edge with stations extending up to $100 \mathrm{~km}$ into the pack and several hundred $\mathrm{km}$ seaward of the ice edge. Winter distributions of bacterial biomass and production were more closely related to local hydrography than to microalgal distributions or the proximity of the ice edge. Bacterial characteristics were highest within or in the proximity of warm-core eddies, enrichments which may have resulted from prior ice melt or from advection of more productive waters. Microalgal characteristics and bacterial production were at their seasonal minimum during the winter cruise; however, bacterial biomass was essentially invariant seasonally and was not as greatly influenced by the location of the ice edge as previously demonstrated for phytoplankton. Similar reports for micrograzers suggest that steady-state conditions apply to much of the microbial food web throughout the year. Bacterial production did not dominate ammonium remineralization processes in winter; instead, ammonium maxima under the ice and near the ice edge were attributed to protozooplankton and higher trophic organisms.
\end{abstract}

KEY WORDS: Antarctica - Weddell Sea - Pack ice - Sea ice - Microhabitats - Microorganisms - Algae Bacteria Phytoplankton Bacterioplankton Primary production - Microbial production B Biomass

\section{INTRODUCTION}

In the Southern Ocean, the apparent paradox of high biomass at upper trophic levels sustained by low phytoplankton biomass and productivity is slowly being reconciled. Spring and autumn investigations in the marginal ice-edge zone (MIZ) of the Weddell-

Present addresses:

- Joint Institute for the Study of the Atmosphere and Ocean, University of Washington, Seattle, Washington 98195, USA

- Division of Biology, 1201 E. California Boulevard, MC 15629, California Institute of Technology, Pasadena, California 91125, USA

-.NSF Office of Polar Programs, Suite 755, 4201 Wilson Boulevard, Arlington, Virginia 22230, USA.
Scotia Sea revealed enhanced biomass and productivity relative to under-ice and open-ocean regions (Ainley et al. 1986, Nelson et al. 1987, 1989, Sullivan et al. 1988, 1990, Cota et al. 1990, Smith \& Nelson 1990), and Smith \& Nelson (1986) estimated that $50 \%$ of Southern Ocean primary productivity occurs within the MIZ. Enhanced primary productivity in the MIZ results from seasonal changes in pack-ice coverage which averages 20 million $\mathrm{km}^{2}$ during austral winter but diminishes to an average 4 million $\mathrm{km}^{2}$ in austral summer (Zwally et al. 1983). This seasonal ice-melt event results in melt-water stratification of a nutrient-rich surface layer seaward of the ice pack (Nelson et al. 1987, 1989), the release of sea ice microbiota into the water column (Garrison \& Buck 1987, 1989b, Kottmeier 
\& Sullivan 1988, 1990), and an increase in the euphotic zone depth. Thus, the MIZ provides an irradiance and nutrient regime favorable for phytoplankton blooms (Sullivan et al. 1988, 1990, Comiso et al. 1990, Smith \& Nelson 1990)

The classic paradigm of organic carbon flow in the Southern Ocean was through an efficient grazing food chain of diatoms, krill, and large carnivores (El-Sayed 1984, Everson 1984). Increasing evidence supports the hypothesis of a microbial loop functioning within sea ice (Kottmeier et al. 1987, Kottmeier \& Sullivan 1990) and in the MIZ (Kottmeier \& Sullivan 1987, 1990, Garrison \& Buck 1989b, Cota et al. 1990, Sullivan et al. 1990). For example, an examination of the seasonal dynamics of the Southern Ocean microbial food web revealed that production of heterotrophic bacteria in the upper $120 \mathrm{~m}$ equaled about $40 \%$ of annual primary production (C. W. Mordy \& C. W. Sullivan unpubl. data). Furthermore, protozooplankton comprised a substantial fraction of the plankton in the WeddellScotia Sea during austral spring, autumn, and winter (Garrison \& Buck 1989a, Garrison et al. 1993). This realization led to the recent hypothesis that production within the microbial food web is an important nutritional source for higher organisms, particularly during austral winter (Azam et al. 1991).

Winter in the Weddell-Scotia Sea is characterized by physicochemical conditions at their seasonal extreme, especially for photosynthetic organisms. Total daily irradiances and oblique sun angle limit both the irradiance and photoperiod within the water column (Kirk 1983, Sakshaug \& Holm-Hansen 1984). Ice cover, which is at its seasonal maximum, diminishes wind driven mixing (Carmack 1986), alters the heat flux out of the ocean (Maykut 1986), and has a high albedo that limits available irradiance and alters its spectral quality in the underlying waters (Maykut \& Grenfell 1975 , Palmisano et al. 1987, Arrigo et al. 1991). These factors are expected to have a profound seasonal influence on microbial rates and processes both in open-water and in the water column underneath the ice.

Relatively low rates of autotrophic production were observed in the Weddell-Scotia Sea during winter (Cota et al. 1992) which, in turn, influenced the structure of upper marine food webs (Ainley et al. 1991) and productivity within the microbial loop (Garrison et al. 1993). Although autotrophic production of organic substrates (photosynthate) may be lower in the MIZ during winter, heterotrophic microorganisms such as bacteria may satisfy a portion of their nutritional demand by direct uptake of inorganic nitrogen (Cota et al. 1992), by utilization of organic substrates released from pack ice during local ice-melt events (Muench et al. 1990), or by utilization of organic substrates produced weeks or months earlier (Azam et al. 1991).
To better understand what factors influence the distribution and production of bacteria in winter, we describe results from the Antarctic Marine Ecosystem Research at the Ice-edge Zone (AMERIEZ) program. This program was designed to investigate seasonal changes in the distribution and activities of organisms associated with the MIZ of the western Weddell and Scotia Seas and to describe the manner by which sea ice dynamics influence the structure and function of the Antarctic pack ice ecosystem. (Ainley \& Sullivan 1984, 1989, Sullivan \& Ainley 1987). The objective of investigators on the third AMERIEZ cruise was to examine ice-edge ecology during austral winter (9 June to 13 August 1988) as described by Ainley \& Sullivan (1989). Here we describe the standing crop and activity of bacterioplankton associated with the winter ice edge, and examine the seasonal variability of bacterial biomass and production within the iceedge ecosystem. Bacterioplankton biomass and production were measured at open-water and under-ice stations, and these data were related to other biological and physical features of the MIZ.

\section{MATERIALS AND METHODS}

Over 300 measurements were made of bacterioplankton biomass and productivity in under-ice and open-water environments of the Weddell-Scotia Sea MIZ as part of the AMERIEZ 1988 winter cruise. Analysis of local hydrography (Muench et al. 1990) and of nutrient and biogenic particulate distributions (Cota et al. 1992) have previously been described.

Sampling. Under-ice and open-water environments were studied in the Weddell-Scotia Sea confluence in June and July 1988 aboard RV 'Polar Duke'. A total of 41 stations were sampled during 3 rapid transects (RT-1, RT-2, and RT-4) across the MIZ (Fig. 1). These transects were 200 to $300 \mathrm{~km}$ long, and were sampled in less than $3 \mathrm{~d}$ : June 16 to 18 for RT-1, July 2 to 5 for RT-2, and July 26 to 28 for RT-4. The purpose of rapid transects was to generate a synoptic view of biological rate processes in the ice-edge zone. At each station, conductivity-temperature-depth (CTD) profiles were conducted using a Sea Bird model SBE 9/11 profiling system. Water samples were collected in $10 \mathrm{l}$ Niskin bottles at $150 \mathrm{~m}$ and at 7 depths corresponding to 100 , $50,30,15,5.0,1.0$, and $0.1 \%$ surface irradiance at open-water stations. If stations were sampled after dark, if stations were in ice-covered waters, or if optical measurements could not be made, optical depths from the most recently completed daylight cast were used. A. Biospherical Instruments Inc. Model MER1010 submersible spectroradiometer was used to generate vertical irradiance profiles and to estimate opti- 


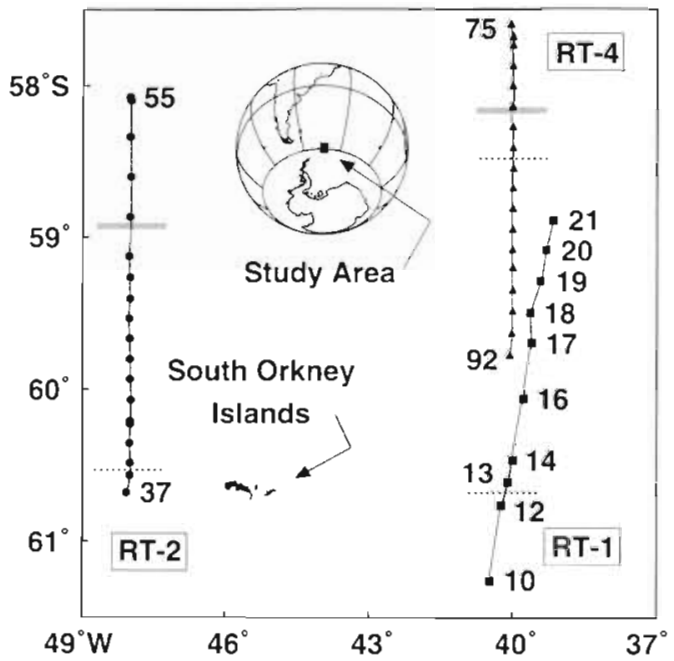

Fig. 1. AMERIEZ 1988 study area in the confluence of the Weddell and Scotia Seas, station locations and numbers

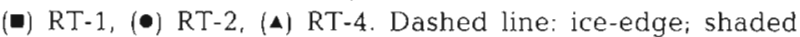
bar: Scotia Front. Stns 11 and 15 were not sampled

cal depths. After recovery, samples were transfered to 201 polypropylene carboys and subsampled for analysis. Samples were usually processed within $0.5 \mathrm{~h}$, but some samples were held in the dark at sea surface temperature (SST) for up to $4 \mathrm{~h}$. Integrated values are to $120 \mathrm{~m}$, which was the approximate depth of the $0.1 \%$ light level in open-water (114 to $123 \mathrm{~m}$ ).

Bacterial biomass and productivity. Bacterial enumeration and biomass estimates were performed using $40 \mathrm{ml}$ of sample preserved with EM grade $1 \%$ glutaraldehyde (final concentration). Bacterial cell numbers were estimated by staining samples with $0.005 \%$ acridine orange (final concentration), filtering onto $0.22 \mu \mathrm{m}$ Nuclepore filters stained with irgalan black, and counting 10 fields or 200 bacteria using a Zeiss epifluorescent microscope fitted with a Zeiss 487709 filter (Hobbie et al. 1977). Biovolume was estimated by measuring the length and width of individual cells with an optical micrometer and by assuming cocci to be spherical and rods to be cylindrical with hemispherical ends. Cell volumes were multiplied by $220 \mathrm{fg} \mathrm{C}$ $\mu^{-3}$ to obtain estimates of cell carbon (Bratbak \& Dundas 1984).

Bacterial productivity was estimated from rates of $\left[{ }^{3} \mathrm{H}\right]$-thymidine incorporation into cold trichloroacetic acid (TCA)-insoluble material (Fuhrman \& Azam 1980, 1982). For each sample, $50 \mathrm{ml}$ replicates and one $50 \mathrm{ml}$ $\mathrm{HgCl}_{2}$ killed control (1.0 $\mu \mathrm{M} \mathrm{HgCl}_{2}$ final concentration) were inoculated with methyl- ${ }^{3} \mathrm{H}$-thymidine $(2481 \mathrm{GBq}$ $\mathrm{mmol}^{-1}$ specific activity; ICN, Costa Mesa, CA, USA) to a final concentration of $10 \mathrm{nM}$ thymidine. All samples were incubated in the dark for 16 to $30 \mathrm{~h}$ at $-1.8^{\circ} \mathrm{C}$ (in situ SST) in an insulated ice chest containing a mixture of about $10 \%$ sea ice in seawater. Uptake of $\left[{ }^{3} \mathrm{H}\right]-$ thymidine was terminated by sample filtration through a $0.45 \mu \mathrm{m}$ Millipore filter (vacuum $=5 \mathrm{~cm} \mathrm{Hg}$ ). Particulates retained on the filter were rinsed twice with filtered seawater (seawater which had passed a $0.22 \mu \mathrm{m}$ filter), extracted with $5 \mathrm{ml}$ ice-cold $5 \%$ TCA for $5 \mathrm{~min}$, and rinsed twice with ice-cold 5\% TCA. (Purification of ${ }^{3} \mathrm{H}$-labeled macromolecular fractions by acid, base, or enzyme hydrolysis did not greatly improve the recovery of ${ }^{3} \mathrm{H}$-precursors compared to cold TCA extraction alone; S. T. Kottmeier \& C. W. Sullivan unpubl.) Filters were placed into scintillation vials and returned to the University of Southern California for counting. A total of $3 \mathrm{ml}$ of Scintiverse (Fisher, Pittsburgh, PA, USA) was added to each vial, and the vials were counted on an LKB 1211 Rackbeta liquid scintillation counter using external standard ratio correction. Rates of $\left[{ }^{3} \mathrm{H}\right]$-thymidine incorporation were corrected for the fraction of incorporated label found in DNA as determined by treatment of filters with DNase. To convert rates of $\left[{ }^{3} \mathrm{H}\right]$-thymidine incorporation to bacterial cell productivity, we used a factor of $2.05 \times 10^{18}$ cells $\mathrm{mol}^{-1}$ of thymidine incorporated (Riemann et al. 1982).

\section{RESULTS}

The spatial distribution of chlorophyll $a_{1}(\mathrm{chl} a)$ and bacterioplankton biomass and activity in the MIZ are displayed in vertical profiles of the upper water column for RT-1, RT-2, and RT-4 in Figs. 2, 3 \& 4 respectively. These figures include the local hydrography as profiles of $\sigma_{t}$ or temperature (A), chl a (B), bacterial biomass (C), and bacterial production (D). The local hydrography (Muench et al. 1990), as well as the distribution of nutrients and biogenic particulates (Cota et al. 1992), has previously been described.

During RT-1, bacterial measurements extended about $70 \mathrm{~km}$ into the ice (Fig. 2). The $-1.8^{\circ} \mathrm{C}$ isotherm was present at all ice-covered stations suggesting little concurrent ice melt (Muench et al. 1990); however, a low salinity, weakly stratified lens observed just north of the ice edge (Fig. 2A) was attributed to a recent ice-melt event (Muench et al. 1990). Chl a concentrations along RT-1 generally increased towards the surface and northward from $<0.04 \mathrm{mg} \mathrm{m}^{-3}$ under the ice to $>0.12 \mathrm{mg} \mathrm{m}^{-3}$ for much of the upper water column at the northern end of the transect (Fig. 2B). Unlike chl $a$, low concentrations of bacterial biomass (<3 $\mathrm{mg} \mathrm{C} \mathrm{m}^{-3}$ ) were observed at several depths for all stations north of the ice edge (Fig. 2C). Furthermore, most of the highest values of bacterial biomass ( $>5 \mathrm{mg}$ $\mathrm{C} \mathrm{m}^{-3}$ ) and production (>0.30 $\mathrm{mg} \mathrm{C} \mathrm{m}^{-3}$ ) were not observed at the northern extreme of RT-1 as for chl $a_{\text {, }}$ but were coincident in a region at the northern edge 


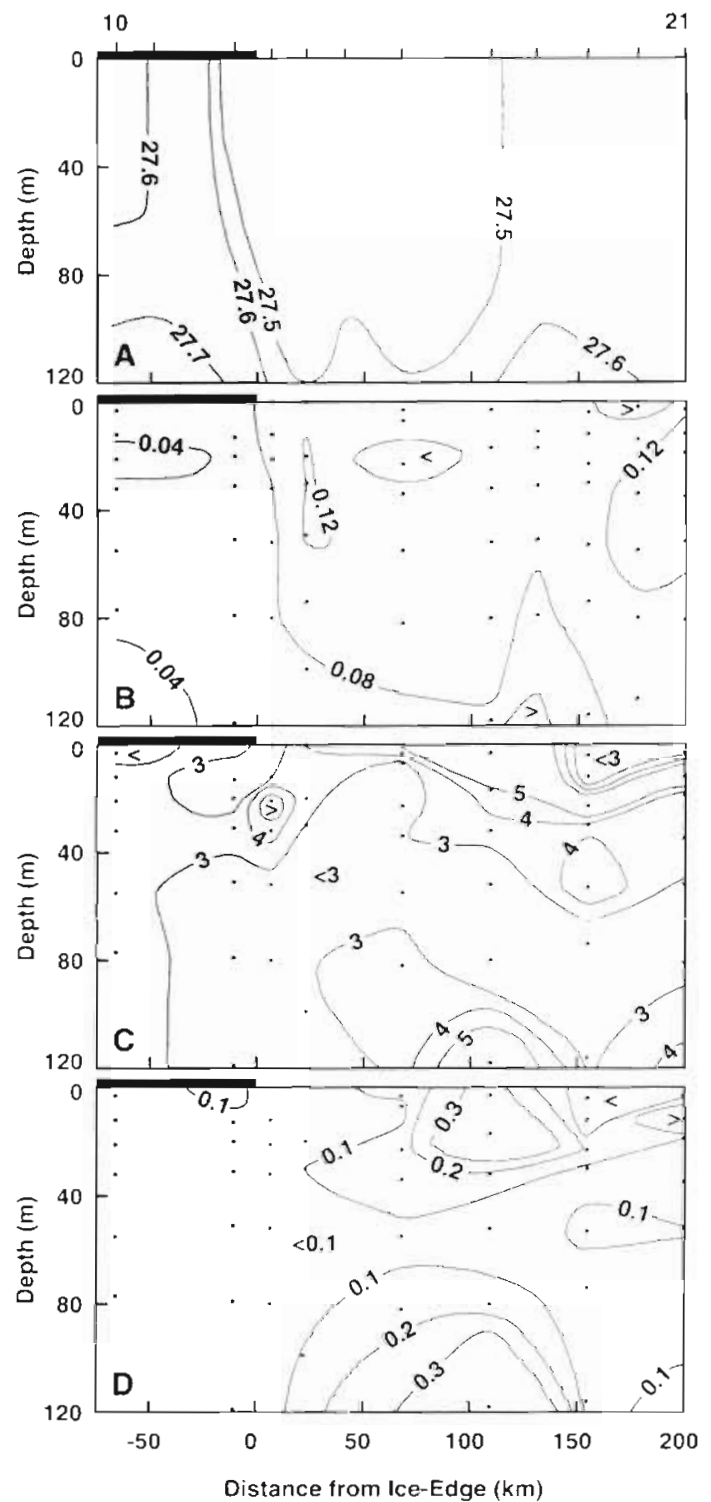

Fig. 2. Vertical profiles of physical and microbial parameters from RT-1 (A) $\sigma_{t}$ contour interval $0.1 \mathrm{~kg} \mathrm{~m}^{-3}$; (B) chl $a_{1}$ contour interval $0.04 \mathrm{mg} \mathrm{m}^{-3}$; (C) bacterial biomass, contour interval $1 \mathrm{mg} \mathrm{C} \mathrm{m}{ }^{-3}$ : (D) bacterial biomass productivity, contour interval $0.1 \mathrm{mg} \mathrm{C} \mathrm{m} \mathrm{m}^{-3} \mathrm{~d}^{-1}$ Station locations and station numbers shown at the top of the figure. Bar atop each graph: pack ice; shaded regions: ice-covered waters

of the melt lens and observed both at the surface and at $120 \mathrm{~m}$ (Fig. 2C, D).

On RT-2, problems with the CTD profiling system compromised salinity and derived density data; therefore, the vertical profile of temperature along this transect has been presented (Fig. 3A). The $-1.8^{\circ} \mathrm{C}$ isotherm extended about $80 \mathrm{~km}$ north of the ice edge, suggesting little ice melt in the region. Rising isotherms and the resulting warmer temperatures $\left(>0.0^{\circ} \mathrm{C}\right)$ observed near the northern end of the transect were from an

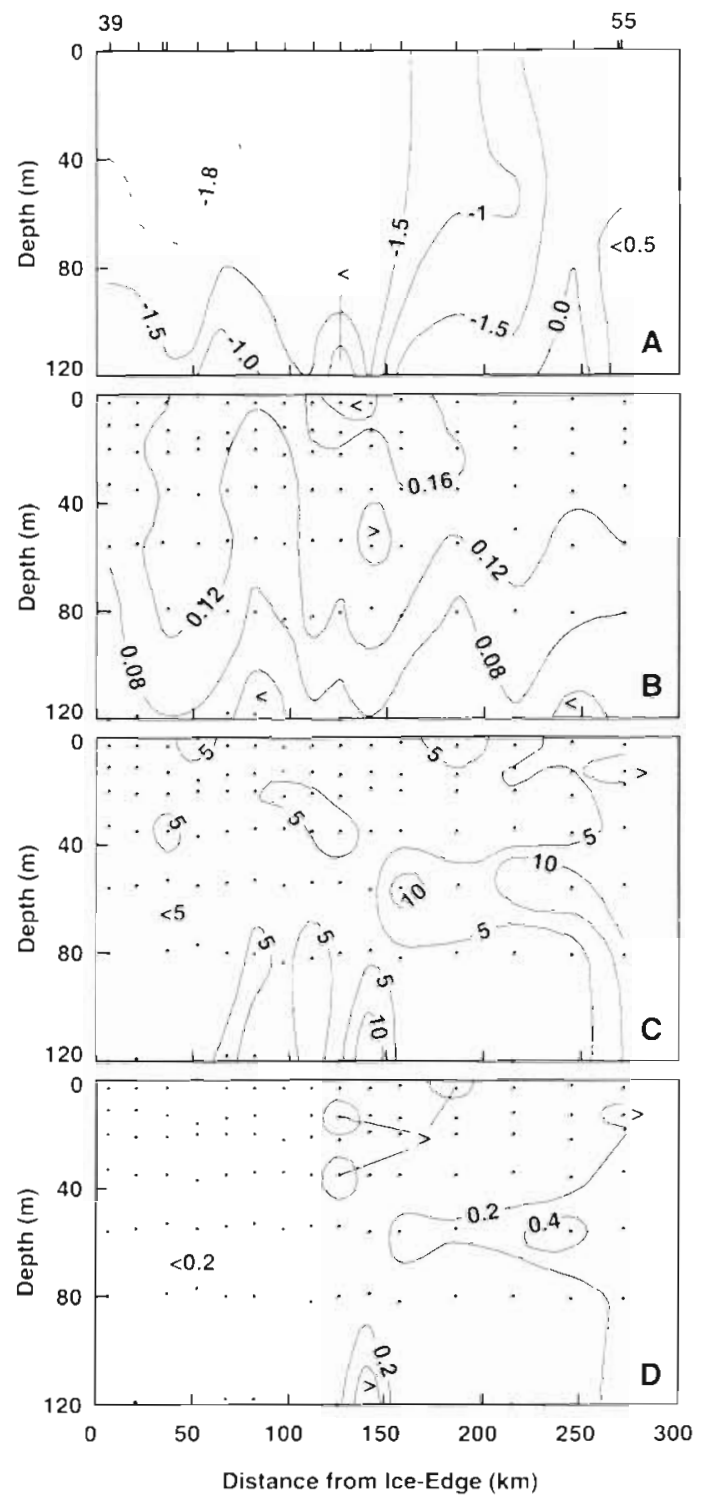

Fig. 3. Vertical profiles of RT-2 identical to those of RT-1 (see Fig. 2) except that salinity and derived density were not available on this transect, so temperature appears in (A) with a contour interval of $0.5^{\circ} \mathrm{C}$ and the freezing point of seawater $\left(-1.8^{\circ} \mathrm{C}\right)$ signified by a dashed line; also, contour intervals for (C) bacterial biomass and (D) productivity were $5 \mathrm{mg} \mathrm{C \textrm { } \mathrm { m } ^ { - 3 }}$ and $0.2 \mathrm{mg} \mathrm{C} \mathrm{m} \mathrm{m}^{-3} \mathrm{~d}^{-1}$ respectively. The southernmost data are from Stn 39 as bacterial biomass and production were not measured at Stns 37 and 38

upward tongue of warmer $\left(>1.5^{\circ} \mathrm{C}\right)$ Circumpolar Deep Water centered at about $400 \mathrm{~m}$, which signified waters of the Scotia Front. Chl a concentrations generally increased toward the surface and were significantly higher than along RT-1. Maximal concentrations $\left(>0.16 \mathrm{mg} \mathrm{m}^{-3}\right.$ ) were observed in near-surface waters at the center of the transect (Fig. 3B). Vertical profiles of bacterial biomass and production show a similar dis- 


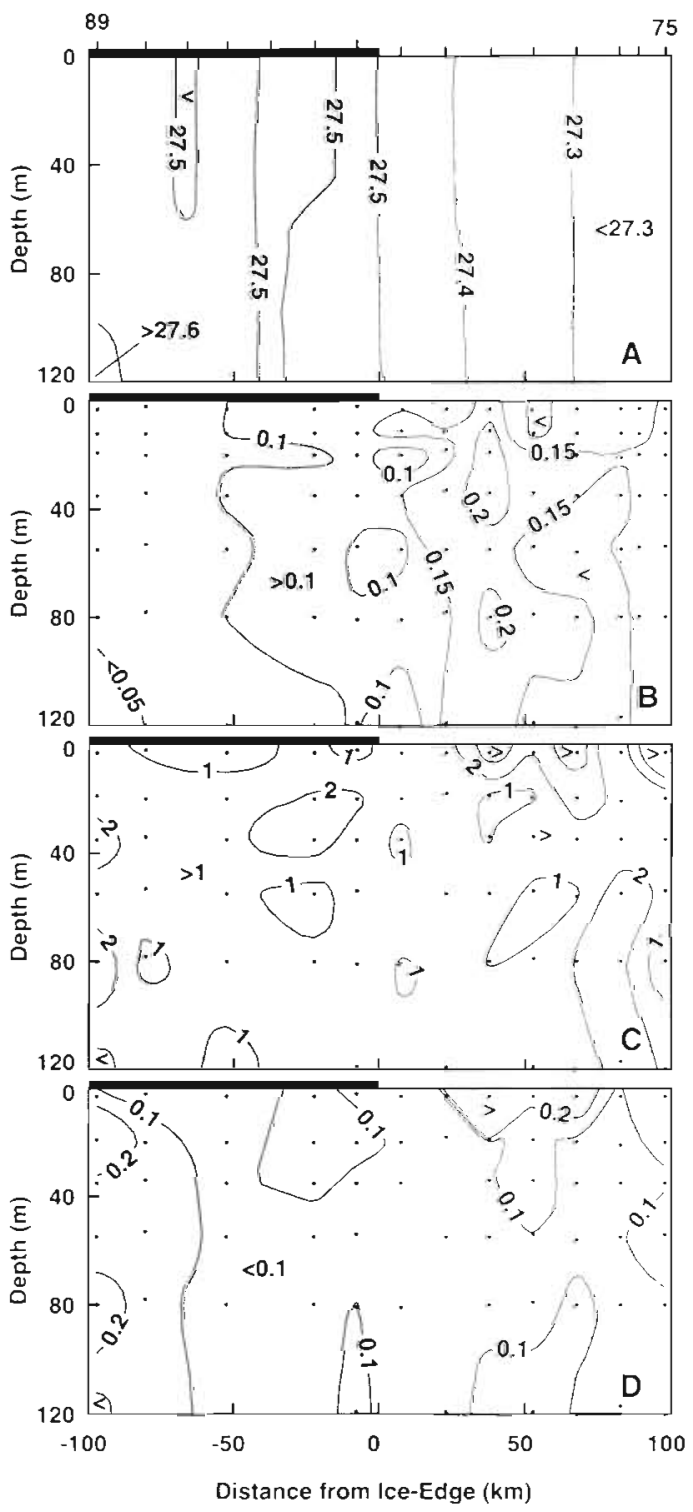

Fig. 4. Vertical profiles of RT-4 identical to those of RT-1 (see Fig. 2) except that (B) chl a had a contour interval of $0.05 \mathrm{mg}$ $\mathrm{C} \mathrm{m}^{-3}$. The southernmost data are from Stn 89 as bacterial biomass and production were not measured at Stns 90 to 92

tribution (Fig. 3C, D) with values near the Scotia Front at the northern end of the transect 2 to 3 times that observed at the ice edge. As with chl a concentrations, bacterial biomass along RT-2 was 2 to 3 times greater than for RT-1.

Almost half of the bacterial stations along RT- 4 were in ice-covered waters with measurements up to $100 \mathrm{~km}$ south of the ice edge (Fig. 4). Vertical profiles of $\sigma_{t}$ indicate little if any horizontal structure (Fig. 4A). Openwater stations north of Stn 79 were in a meander or eddy containing warmer $\left(>0.0^{\circ} \mathrm{C}\right)$ Polar Front Water (Muench et al. 1990). Chl a concentrations at open- water stations ranged from about 0.1 to $0.15 \mathrm{mg} \mathrm{m}^{-3}$ throughout most of the upper water column with concentrations $>0.2 \mathrm{mg} \mathrm{m}^{-3}$ observed about $40 \mathrm{~km}$ north of the ice edge (Fig. 4B). Under the pack ice, chl a concentrations decreased southward to $<0.05 \mathrm{mg} \mathrm{m}^{-3}$. The range of bacterial biomass along RT-4 was considerably less than that observed on previous transects with concentrations $>3 \mathrm{mg} \mathrm{C} \mathrm{m}^{-3}$ observed only in warmer water north of the ice edge (Fig. $4 \mathrm{C}$ ). Relatively low rates of bacterial production $\left(<0.1 \mathrm{mg} \mathrm{C} \mathrm{m}^{-3} \mathrm{~d}^{-1}\right)$ were observed along most of the transect with the highest production ( $>0.2 \mathrm{mg} \mathrm{C} \mathrm{m} \mathrm{m}^{-3} \mathrm{~d}^{-1}$ ) measured about $100 \mathrm{~km}$ south of the ice edge and in surface waters north of the ice edge (Fig. 4D).

Chl a, bacterial biomass, and bacterial production integrated to $120 \mathrm{~m}$ for each of the transects are shown relative to the ice edge in Fig. 5. For each transect, chI a standing stocks varied about 3 -fold with the lowest stocks observed under the pack ice (Fig. 5A). Chl a standing stocks were generally higher along RT-4. The highest chl a stocks observed for the 3 transects were in or near warmer waters of Polar Front north of the ice edge along RT-4. Unlike chl a stocks, there was no significant difference between under-ice and open-water bacterioplankton biomass for RT-1 and RT-4 (Fig. 5B). Moreover, bacterioplankton standing stocks were lowest along RT-4, even in Polar Front waters. The highest bacterioplankton standing stocks were observed at the northern termini of RT-2; stations furthest from and perhaps least influenced by the presence of sea ice and stations within warmer waters of the Scotia Front. In contrast to bacterioplankton standing stocks, there was considerable variability in integrated bacterial production for RT-1 and RT-4 (Fig. 5C). The distribution of integrated bacterial productivity for RT-1 was similar to, albeit 2 - to 4 -fold less than, observed spring distributions (Sullivan et al. 1990), that is, low values under the pack ice, high values 50 to $100 \mathrm{~km}$ from the ice edge, and intermediate values more distant from the ice edge. For RT-4, relatively high production was observed at both under-ice and open-water stations. The distribution of integrated bacterial production along RT-2 was not greatly different than that for bacterial biomass with the highest values in warmer waters at the northern end of the transect.

\section{DISCUSSION}

\section{Hydrography}

Mesoscale spatial zonation of winter bacterial biomass and production was significantly influenced by local physical oceanographic structure and ice dynamics. The hydrographic regime of the Weddell-Scotia 


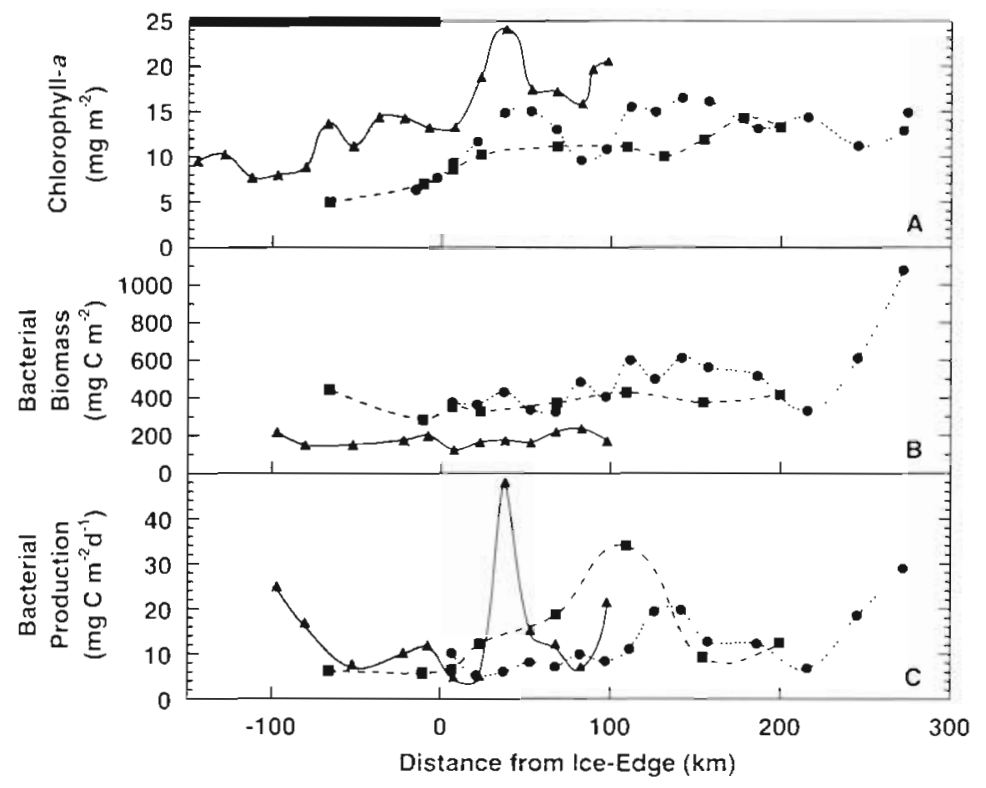

Fig. 5. Integrated (A) chl a ( $\left.\mathrm{mg} \mathrm{m}^{-2}\right)$, (B) bacterial biomass $\left(\mathrm{mg} \mathrm{C} \mathrm{m}^{-2}\right)$, and

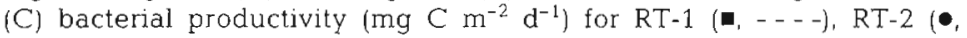
........), and RT-4 (4, — in relation to the ice-edge. Bar atop each graph: pack ice; shaded regions: ice-covered waters

confluence (WSC) during winter has been discussed in detail by Muench et al. (1990), and biologically relevant information will be briefly summarized. The study area (Fig. 1), which was chosen because of the location of the ice edge (Ainley \& Sullivan 1989), was in the complex hydrographic region of the WSC. The WSC in the southern central Scotia Sea is a region where outflowing colder waters of the Weddell Sea converge and mix with eastward flowing warmer water of the Scotia Sea. A third water type identified in the southern Scotia Sea during summer, water modified by continental margins or by air-sea exchange, was not evident in the winter of 1988. The WSC is bounded to the north and south by the Scotia and Weddell Fronts, respectively. The Scotia Front separates the WSC from Antarctic water and has been defined by the $1.5^{\circ} \mathrm{C}$ isotherm in the Circumpolar Deep Water (Patterson \& Sievers 1980). Both RT-2 and RT-4 crossed this frontal feature; however, accurate CTD data below the pycnocline were not available on RT-1, thus, it could not be determined if the Scotia Front was encountered during RT1. Also, due to the wide longitudinal spacing of the transects, it was unclear if the Scotia Front was a continuous east-west feature at this time

The study region was dominated by mesoscale eddies and/or meanders, typically anticyclonic warm core features. One of these features, either a meander or an eddy, had mixed into the Scotia Sea and was observed at the northern end of RT-4 with $\sigma_{t}$ at the core $<27.3$ (Fig. 4A) A near-surface-drogued Argos- tracked drifter was entrained in a second feature, an eddy migrating eastward at approximately $5 \mathrm{~cm} \mathrm{~s}^{-1}$. This eddy, which had a diameter of about $100 \mathrm{~km}$, was centered about $55 \mathrm{~km}$ east of the northern terminal of RT-2 in late July, $18 \mathrm{~d}$ after measurements were made along $\mathrm{RT}-2$. If the rate and direction of eddy drift were constant, the eddy would have been centered about $30 \mathrm{~km}$ northeast of the northern terminal of RT-2 when samples at this location were collected. Relatively cold temperatures $\left(<0.0^{\circ} \mathrm{C}\right)$ at the northern end of RT-2 indicate that the warm core $\left(>0.0^{\circ} \mathrm{C}\right)$ eddy was not centered about this location; however, this feature may have exerted some influence on the local hydrography and biology.

The pack ice advanced about $200 \mathrm{~km}$ northward between RT-1 and RT-4 from about $60^{\circ} 40^{\prime} \mathrm{S}$ to $58^{\circ} 30^{\prime} \mathrm{S}$ (Fig. 1). Ice movement northward was attributed primarily to wind forcing rather than new ice formation as evidenced by (i) under-ice SSTs which were $>-1.8^{\circ} \mathrm{C}$ on $\mathrm{RT}-4$, the temperature at which seawater begins to freeze, and (2) the paucity of frazil or pancake ice observed from the ship. Although new ice formation is the dominant process affecting the extent of ice cover in winter (Zwally et al. 1983), localized ice-melt events did occur. For example, a low salinity, low density lens observed $50 \mathrm{~km}$ north of the ice edge during RT-1 (Fig. 2A) was attributed to ice melting. Ice melt likely resulted from advection of the pack northward into warmer waters of the Antarctic Convergence or from the penetration of warm core eddies into the pack. In fact the southern Scotia Sea in winter has been considered a region of ice melt and not one of new ice formation (Muench et al. 1990).

\section{Mesoscale spatial zonation in winter}

Winter is the most extreme season for photoautotrophic organisms due to low irradiance levels, short photoperiods (Sakshaug \& Holm-Hansen 1984) and deep vertical mixing. Furthermore, snow and pack ice cover about 20 million $\mathrm{km}^{2}$ of the Southern Ocean in winter (Zwally et al. 1983), and attenuate about $99 \%$ of incident irradiance (Palmisano et al. 1987). The influence of ice coverage on photosynthetic organisms was demonstrated by significantly lower chl a standing stocks in ice-covered waters relative to open waters for each of the transects (Fig. 5A). Yet, ice coverage did not influence bacterial biomass and production in a similar fashion. There was no significant difference 
between bacterial biomass in ice-covered and open waters on RT-1 and RT4 (Fig. 5B). Also, bacterial production along RT-4 had maxima in both icecovered and open waters (Figs, 4D \& 5C).

A simplistic view of the winter MIZ which divides the region into under-ice and open-water environments masks the complex hydrodynamics influencing the distribution and production of biological material. For example, the distribution of chl $a$ in spring was influenced by the presence of several water masses, and the highest chl a concentrations were observed within an oceanographic front (Nelson et al. 1987). Similarly, the highest bacterial production on RT-4 was observed within a warm-core eddy (Fig. 5C). Also, bacterial biomass and production maxima observed at the northern extreme of RT-2 were far removed from the ice edge (Figs. 3 \& 5) and were in waters either representative of or influenced by a second warm-core eddy. It appears that winter distributions of bacterial biomass and production were less influenced by ice coverage than by the presence of various water types and oceanographic fronts.

On RT-1, bacterial biomass and activity maxima were observed about $100 \mathrm{~km}$ north of the ice edge in a weakly stratified, degrading melt lens (Fig. 2C, D). Sea ice was enriched in bacterial biomass and detrital material (Kottmeier \& Sullivan 1987, 1990) and could have released large quantities of organic material, including bacterial substrates, into the upper water column. Hence, while low levels of solar irradiance limit winter primary production, increased microbial production near a melting ice edge might still occur. We cannot determine whether enhanced bacterial biomass resulted from deposition of biomass from the ice, from in situ growth of bacterial communities within a melt-water lens, or from advection from another region of the Southern Ocean. The ice-melt event encountered during RT-1 did not increase integrated bacterial biomass or chl a for this region, thus, we conclude that episodic ice-melt events in winter exert only a small spatial and/or temporal influence on these distributions.

Ammonium maxima were generally observed in icecovered waters and in open waters near the ice edge. Concentrations in these maxima exceeded $1 \mu \mathrm{M}$ early in the cruise and were about 1.5- to 10 -fold higher than values in waters more distant from the ice edge (<0.1 to $0.9 \mu \mathrm{M}_{\mathrm{i}} \mathrm{L}$. Gordon pers. comm.). Cota et al. (1990) considered these maxima to result from decomposition of organic nitrogen and/or excretion by heterotrophs. While bacterial production may have contributed ammonium to the upper water column, bacterial production and ammonium were not spatially coherent nor significantly correlated $\left(r^{2}=0.003, n=\right.$ 211) suggesting that other sources of ammonium were significant. Ammonium concentrations within the winter pack ice were typically 5- to 30-fold higher than in open waters (C. H. Fritsen, C. W. Mordy \& C. W. Sullivan unpubl.); therefore, ice melt could potentially release significant concentrations of ammonium into the water column. But in winter, the mixed layer was sufficiently deep (temperatures and $\sigma_{t}$ were usually vertically homogeneous in the upper $100 \mathrm{~m}$; Muench et al. 1990) so that ice melt alone could not account for the maxima observed. These results suggest that hetero- 
trophic organisms other than bacteria may have been active near the ice edge, and could have contributed significant amounts of ammonium to the water column.

Major bacteriovores in the MIZ of the Weddell-Scotia Sea were microheterotrophic flagellates and ciliates and, to a lesser extent, larger ( 50 to $300 \mu \mathrm{m}$ ) protozooplankton, including radiolarians, foraminifera, heliozoans, and some ciliates (Garrison \& Buck 1987, 1989a, b, Garrison et al. 1993), organisms which potentially couple bacterioplankton productivity to higher trophic levels. Spring and autumn distributions of protozooplankton biomass were significantly influenced by the ice edge as higher standing stocks were consistently observed seaward of the ice edge (Garrison \& Buck 1989 b). Furthermore, protozooplankton were thought to predominate ammonium remineralization processes in the spring MIZ (Goeyens et al. 1991). In winter, average standing stocks of protozooplankton were not greatly difterent than for spring or autumn; however, their distributions were not related to ice cover (Garrison et al. 1993). Such protozooplankton distributions in winter might argue against protozooplankton as significant ammonium remineraỉzers because ammonium maxima were generally observed under or near the ice edge. Yet biomass-dependent estimates of protozooplankton respiration in winter greatly exceeded bacterial production and demonstrated the potential influence of these organisms in ammonium remineralization processes in the MIZ (Garrison et al. 1993).

In winter, phytoplankton grazers were seasonally displaced towards the surface and were thought to be sustained largely by autotrophic production within pack ice (Ainley et al. 1991). Furthermore, large concentrations of young Euphausia superba were observed feeding on the undersides of ice floes (Daly 1990), and swarms of larval, juvenile, and immature adult $E$. superba were observed near the ice edge, with mean abundance in the MIZ 5- to 10-fold higher than in open water (Daly \& Macaulay 1991). While the abundance of $E$. superba was difficult to determine (plummet net catches underestimated E. superba biomass; Hopkins et al. 1993), upper trophic levels (zooplankton and their predators) were perhaps a significant source of ammonium in the upper water column of the MIZ during winter.

\section{Seasonal mesoscale spatial zonation}

As the Southern Ocean south of the polar front is generally replete with macronutrients, stratification of the upper water column in the MIZ has been considered the most important factor for the development of phytoplankton blooms, and in determining the mesoscale spatial zonation of phytoplankton biomass and productivity (Nelson et al. 1987, 1989, Sullivan et al. 1988, Comiso et al. 1990, Smith \& Nelson 1990). Ice ablation in spring and autumn resulted in strong horizontal gradients and reduced vertical mixing seaward of the ice edge, conditions which persisted even after the ice edge became stationary (Nelson et al. 1989). Furthermore, removal of snow and ice cover significantly increased the photic zone depth (Palmisano et al. 1987). Thus spring and autumn were seasons during which ice melt and longer photoperiod dramatically improved the irradiance regime seaward of the ice edge. As a result, mean chl a standing stocks and bacterial biomass and productivity in spring and autumn were higher in ice-free waters than in icecovered waters (Cota et al. 1990). In spring, similar distributions of chl a and bacterial biomass and production over the strong physio-optical gradients about the ice edge suggested at least mesoscale coupling of autotrophs and bacteria (Sullivan et al. 1990).

Seasonal dynamics in the hydrography and in the mesoscale spatial zonation of autotrophic production were dramatic within the MIZ (Fig. 6). In austral spring, 1983 , the ice edge was diffuse and had recentiy begun its annual retreat (Comiso \& Sullivan 1986, Sullivan et al. 1990). Ice-free waters were moderately stratified and had the highest chl a content and autotrophic production observed for any season with maxima 100 to $300 \mathrm{~km}$ seaward of the ice edge (Fig. 6A, B). These results were consistent with the hypothesis that, during ice ablation, algal bloom development was spatially oriented to the ice edge; that is, the earliest stages of bloom development were adjacent to the ice edge, the greatest accumulations of algal biomass were in older stratified water more distant from the ice edge, and the seaward extent of the bloom was delineated by deep wind mixing and erosion of upper water stratification (Nelson et al. 1987. Sullivan et al. 1988).

In austral autumn, 1986, pack ice coverage in the Antarctic was at its seasonal minimum, and the welldefined ice edge remained almost stationary during the study (Nelson et al. 1989). Oceanographic conditions appeared favorable for abundant algal growth. An intense pycnocline vertically stratified the upper 30 to $50 \mathrm{~m}$ of the water column throughout the study area, and micronutrient concentrations in the upper stratified layer remained relatively high (Nelson et al. 1989). Unexpectedly, standing stocks of chl a and autotrophic production in ice-free waters were considerably lower than in spring (Fig. 6A, B) and were perhaps indicative of decaying bloom conditions. Possible factors limiting chl a accumulations and photosynthesis in autumn include light limitation throughout much of the euphotic zone, grazing or other removal processes, and micronutrient limitation (Nelson et al. 1989). 
While satellite images in autumn show modest chl a concentrations in the study area, extensive accumulations of chl a were observed at several ice-edge locations south of our study area, suggesting that conditions in the Southern Ocean were not wholly insufficient for algal growth and accumulation (Comiso et al. 1990). These images in combination with springtime satellite images (Sullivan et al. 1988) emphasize the spatial variability of the region, and imply that apparent seasonal dynamics of chl a stocks in Fig. 6A may, to a large extent, be spatially derived.

All microalgal characteristics measured during winter represent seasonal minima for our seasonal investigations. Even though local ice melt weakly stratified the upper water column in winter, the short photoperiod and low sun angle resulted in minimal, lightlimited autotrophic production and minimal chl $a$ standing stocks (Fig. 6A, B). Relative to observations in spring and autumn, average chl a standing stocks and autotrophic production were 2- to 15-fold lower in winter, and chl a standing stocks were not greatly enhanced in open waters (Fig. 6A, B).

Autotrophic production in ice-covered waters was not measured at in situ irradiance levels and therefore has not been discussed. Based on previous studies in other regions (Kottmeier \& Sullivan 1990), attenuation of incident irradiance by snow and ice cover most likely resulted in severe reductions in autotrophic production. Similar chl a concentrations in winter and for ice-covered waters in spring and autumn (Fig. 6A) suggest that either ice coverage resulted in winter-like water column production or that both under-ice autotrophic production and grazing were intensified in spring and autumn. Without knowledge of in situ autotrophic production for under-ice waters, we cannot unambiguously distinguish between these possibilities; however, previous reports of low under-ice stocks of microzooplankton and zooplankton grazers during these seasons favor the former interpretation (Hopkins \& Torres 1988, Garrison \& Buck 1989a).

Although seasonal distributions of chl a and autotrophic production varied dramatically, bacterial biomass and abundance remained remarkably stable. Bacterial numbers ranged from $7 \times 10^{9}$ to $7 \times 10^{11}$ cells $\mathrm{m}^{-3}$, results consistent with previous studies in the Antarctic from various seasons and from both coastal and open waters (see Table 4 in Cota et al. 1990 for many references prior to 1990; also Zdanowski 1982, 1985, Mullins \& Priddle 1987, Karl et al. 1991, Kim 1991, Fiala \& Delille 1992, Kuparinen \& Bjornsen 1992). Likewise, in spite of the large seasonal fluctuations in autotrophic production, standing stocks of protozooplankton (Garrison et al. 1993) and zooplankton (Atkinson \& Peck 1988, Lancraft et al. 1989) were relatively invariant seasonally. Together, these results imply steady-state conditions for much of the lower food web in the Antarctic throughout the year

Recently, Zdanowski \& Donachie (1993) enumerated bacteria in waters just east of the South Orkney Islands and within $100 \mathrm{~km}$ of the ice edge during austral summer. They found mean bacterial concentrations of $6 x$ $10^{9}$ cells $\mathrm{m}^{-3}$, values which were significantly lower than previous studies and lower than any sample measured during our seasonal study. Because other reports of summertime bacterial abundance were consistently higher, they attributed these differences to spatial and not seasonal variability. Yet, we investigated a much larger geographic region within the MIZ than Zdanowski \& Donachie (1993), and unusually high spatial variability of bacterial abundance was not observed. While differences between the results presented here and the data of Zdanowski \& Donachie (1993) remain unresolved, it appears that such low bacterial numbers were not common and may represent unique biological and/or hydrographic events on narrow spatial or temporal scales.

During the seasonal ice retreat in spring, the mesoscale spatial zonation of chl a and bacterial biomass were similar, and these parameters were significantly correlated across the MIZ (Sullivan et al. 1990). But in autumn and winter, the distribution of bacterial biomass was not correlated with chl a or with intense seasonal dynamics in the horizontal density structure of the MIZ, nor was bacterial biomass greatly influenced by ice coverage. For example, standing stocks of bacterial biomass were $<2$-fold higher at open-water stations relative to under-ice stations; moreover, this ratio was similar for spring, autumn, and winter at 1.1 to 3.7 (Mordy \& Sullivan unpubl.). Thus, relative to the dramatic seasonal changes observed in chl $\mathrm{a}$, the influence of pack ice coverage on average bacterioplankton standing stocks in the MIZ was small not only in winter (discussed above), but for much of the year.

Unlike bacterial biomass, bacterial production in the MIZ was influenced considerably by ice coverage and by the local hydrography in spring and autumn (Fig. 6D). But in winter, bacterial production was reduced 85 to $90 \%$ relative to spring and autumn; and, even though winter bacterial production within the MIZ ranged over 3 orders of magnitude $(0.001$ to $3.56 \mathrm{mg} \mathrm{C} \mathrm{m}^{-3} \mathrm{~d}^{-1}$ ), there was no significant difference between under-ice and open-water stations. Thus, while the influence of pack ice coverage on average bacterioplankton production in the MIZ was significant in spring and summer, it was relatively small in winter. Also, the spatial variability of bacterial production in winter (Fig. 5C), which was mostly derived from the local hydrography, was minor when compared to the dramatic seasonal changes observed for bacterial production (Fig. 6D). 
Recently, Smetacek et al. (1990) argued that the nutrient-rich Southern Ocean was generally a regenerative system with algal blooms superimposed. This was in stark contrast to the traditional view of nutrientrich regions in which regeneration predominates only after all available micronutrients are consumed by algal growth (Smetacek 1984). Results from the AMERIEZ program support the hypothesis of an active regenerative system despite excessive micronutrients (Garrison et al. 1993). Yet, bacterial production in winter was especially low, was not an especially significant fraction of autotrophic production ( $44 \%$ ), and was not spatially coherent with ammonium concentrations (discussed above). If regeneration was predominant in winter, it does not appear that bacteria contributed substantially to the process.

Acknowledgements. We thank M. P. Lizotte, W. S. Chamberlin, R. A. Reynolds, and K. Boettcher for their assistance in the field, M. Hamilton for his computer expertise, and the captain and crew of the RV 'Polar Duke'. This work was supported by NSF/DPP grants to C.W.S. This is the Joint Institute for the Study of Atmosphere and Ocean contribution 300, and PMEL contribution 1635

\section{LITERATURE CITED}

Ainley DG, Fraser WR, Smith WO Jr, Hopkins TL, Torres JJ (1991) The structure of upper level pelagic food webs in the Antarctic: effect of phytoplankton distribution. J mar Syst 2:111-122

Ainley DG, Fraser WR, Sullivan CW, Torres JJ, Hopkins TL, Smith WO Jr (1986) Antarctic mesopelagic micronekton: evidence from seabirds that pack ice affects community structure. Science 232:847-849

Ainley DG, Sullivan CW (1984) AMERIEZ 1983: a summary of activities on board R/V Melville and USCGC Westwind. Antarctic J US 19:100-102

Ainley DG, Sullivan CW (1989) AMERIEZ 1988: a summary of a winter cruise of the Weddell and Scotia seas on Polar Duke. Antarctic J US 24:144-147

Arrigo KR, Sullivan CW (1991) A bio-optical model of Antarctic sea ice. J Phycol 28:746-756

Atkinson, A, Peck, J M (1988) A summer-winter comparison of zooplankton in the oceanic area around South Georgia. Polar Biol 8:463-473

Azam F, Smith DC, Hollibaugh JT (1991) The role of the microbial loop in Antarctic pelagic ecosystems. In: Sakshaug E, Hopkins CCE, Øritsland NA (eds) Proceedings of the Pro Mare Symposium of polar marine ecology. Trondheim, 12-16 May 1990. Polar Res 10:239-243

Bratbak G, Dundas I (1984) Bacterial dry matter content and biomass estimations. Appl environ Microbiol 48:755-757

Carmack EC (1986) Circulation and mixing in ice-covered waters. In: Untersteiner, $\mathrm{N}$ (ed) The geophysics of sea ice. NATO-ASI Series B: Physics, Vol 146. Plenum Press, New York, p 641-712

Comiso JC, Maynard NG, Smith WO Jr, Sullivan CW (1990) Satellite ocean color studies of Antarctic ice edges in summer and autumn. J geophys Res 95:9481-9496

Comiso JC, Sullivan CW (1986) Satellite microwave and in situ observations of the Weddell Sea ice cover and its marginal ice zone. J geophys Res 91:9663-9681
Cota GF, Kottmeier ST, Robinson DH, Smith WO Jr, Sullivan CW (1990) Bacterioplankton in the marginal ice zone of the Weddell Sea: biomass, production, and metabolic activities during austral autumn. Deep Sea Res 37: $1145-1167$

Cota GF, Smith WO Jr, Nelson DM, Muench RD, Gordon LI (1992) Nutrient and biogenic particulate distributions, primary productivity and nitrogen uptake in the Weddell Scotia Sea marginal ice zone during winter. J mar Res 50:155-181

Daly KL (1990) Overwintering development, growth, and feeding of larval Euphausia superba in the Antarctic marginal ice zone. Limnol Oceanogr 35:1564-1576

Daly KL, Macaulay MC (1991) Influence of physical and biological mesoscale dynamics on the seasonal distribution and behavior of Euphausia superba in the Antarctic marginal ice zone. Mar Ecol Prog Ser 79:37-66

El-Sayed S (1984) Productivity in the Antarctic waters - a reappraisal. In: Holm-Hansen O, Bolis L, Gilles $R$ (eds) Marine phytoplankton and productivity. Springer-Verlag, Berlin, p 19-34

Everson I (1984) Marine interactions. In: Laws RM (ed) Antarctic ecology, Vol 2. Academic Press, London, p 783-819

Fiala M, Delille D (1992) Variability and interactions of phytoplankton and bacterioplankton in the Antarctic neritic area. Mar Ecol Prog Ser 89:135-146

Fuhrman JA, Azam F (1980) Bacterioplankton secondary production estımates for coastal waters of British Columbia Antarctica and California. Appl environ Microbiol 39: $1085-1095$

Fuhrman JA, Azam F (1982) Thymidine incorporation as a measure of heterotrophic bacterioplankton production in marine surface waters: evaluation and field results. Mar Biol 66:109-120

Garrison DL, Buck KR (1987) Algal assemblages in Antarctic pack ice and in ice-edge plankton. J Phycol 23:564-572

Garrison DL, Buck KR (1989a) Protozooplankton in the Weddell Sea, Antarctica: abundance and distribution in the ice-edge zone. Polar Biol 9:341-351

Garrison DL, Buck KR (1989b) The biota of Antarctic pack ice in the Weddell Sea and Antarctic peninsula regions. Polar Biol 10:211-219

Garrison DL, Buck KR, Gowing MM (1993) Winter plankton assemblage in the ice edge zone of the Weddell and Scotia Seas: composition, biomass and spatial distributions. Deep Sea Res 40:311-328

Goeyens L, Trégue, P, Lancelot C, Mathot S, Becquevort S, Morvan J, Dehairs F, Bayens W (1991) Ammonium regeneration in the Scotia-Weddell Confluence area during spring 1988. Mar Ecol Prog Ser 78:241-252

Hobbie JE, Dale, RJ, Jasper S (1977) Use of Nuclepore filters for counting bacteria by fluorescence microscopy. Appl environ Microbiol 33:1225-1228

Hopkins TL, Lancraft TM, Torres JJ, Donnelly J (1993) Community structure and trophic ecology of zooplankton in the Scotia Sea marginal ice zone in winter. Deep Sea Res 40: $81-105$

Hopkins TL, Torres JJ (1988) The zooplankton community in the vicinity of the ice edge, western Weddell Sea, March 1986. Polar Biol 9:79-87

Karl DM, Holm-Hanson O, Taylor GT, Tien G, Bird DF (1991) Microbial biomass and productivity in the western Bransfield Strait, Antarctica during the 1986-1987 austral summer. Deep Sea Res 38:1029-1055

Kim SJ (1991) Bacterial number, heterotrophy and extracellular enzyme activity in the Bransfield Strait, Antarctica. Kieler Meeresforsch Sonderh 8:205-212 
Kirk JTO (1983) Light and photosynthesis in aquatic ecosystems. Cambridge Univ Press, Cambridge, p 24-41

Kottmeier ST, McGrath Grossi S, Sullivan CW (1987) Sea ice microbial communities. VIII. Bacterial production in annual sea ice of McMurdo Sound, Antarctica. Mar Ecol Prog Ser 35:175-186

Kottmeier ST, Sullivan CW (1987) Late winter primary production and bacterial production in sea ice and seawater west of the Antarctic peninsula. Mar Ecol Prog Ser 36: $287-298$

Kottmeier ST, Sullivan CW (1988) Sea ice microbial communities (SIMCO). IX. Effects of temperature and salinity on rates of metabolism and growth of autotrophs and heterotrophs. Polar Biol 8:293-304

Kottmeier ST, Sullivan CW (1990) Bacterial biomass and production in pack ice of Antarctic marginal ice edge zones. Deep Sea Res 37:1311-1330

Kuparinen J, Bjørnsen PK (1992) Spatial distribution of bacterioplankton production across the Weddell-Scotia Confluence during early austral summer 1988-1989. Polar Biol $12: 197-204$

Lancraft TL, Torres JJ, Hopkins TL (1989) Micronekton and macrozooplankton in the open waters near Antarctic ice edge zones (AMERIEZ 1983-1986). Polar Biol 9:225-233

Maykut GA (1986) The surface heat and mass balance. In: Untersteiner $N$ (ed) The geophysics of sea ice. NATO-ASI Series B: Physics, Vol 146. Plenum Press, New York, p $395-464$

Maykut GA, Grenfell TC (1975) The spectral distribution of light beneath first-year sea ice in the Arctic Ocean. Limnol Oceanogr 20:554-563

Muench RD, Gunn JT, Husby DM (1990) The WeddellScotia confluence in midwinter. I geophys Res 95: $18177-18190$

Mullins BW, Priddle J (1987) Relationships between bacteria and phytoplankton in the Bransfield Strait and southern Drake Passage. Br Antarct Surv Bull 76:51-64

Nelson DM, Smith WO Jr, Gordon LI, Huber BA (1987) Spring distributions of density, nutrients, and phytoplankton biomass in the ice edge zone of the Weddell-Scotia Sea J geophys Res 92:7181-7190

Nelson DM, Smith WO Jr, Muench RD, Gordon LI, Sullivan CW, Husby DM (1989) Particulate matter and nutrient distributions in the ice-edge zone of the Weddell Sea: relationship to hydrography during late summer. Deep Sea Res 36:191-209

Palmisano AC, SooHoo JB, Moe RL, Sullivan CW (1987) Sea ice microbial communities. VII. Changes in under ice spectral irradiance during the development of Antarctic sea ice microalgal communities. Mar Ecol Prog Ser 35 $165-173$

This article was submitted to the editor
Patterson SL, Sievers HA (1980) The Weddell-Scotia confluence. J Phys Oceanogr 10:1584-1610

Riemann B, Fuhrman J, Azam F (1982) Bacterial, secondary production in freshwater measured by ${ }^{3} \mathrm{H}$-thymidine incorporation method. Microb Ecol 8:101-114

Sakshaug E, Holm-Hansen $O$ (1984) Factors governing pelagic production in polar oceans. In: Holm-Hansen $\mathrm{O}$, Bolis L, Gilles R (eds) Marine phytoplankton and productivity. Springer-Verlag, Berlin, p 1-18

Smetacek $V(1984)$ The supply of food to the benthos. In: Fasham MJ (ed) Flows of energy and materials in marine ecosystems: theory and practice. Plenum Press, New York, p $517-548$

Smetacek V, Scharek R, Nöthig EM (1990) Seasonal and regional variation in the pelagial and its relationship to the life history cycle of krill. In: Kerry KR, Hempel G (eds) Antarctic ecosystems, ecological change and conservation. Springer-Verlag, Berlin, p 103-114

Smith WO Jr, Nelson DM (1986) Importance of ice edge phytoplankton production in the Southern Ocean. BioSci 36:251-257

Smith WO Jr, Nelson DM (1990) Phytoplankton growth and new production in the Weddell Sea marginal ice zone during spring and autumn. Limnol Oceanogr 35:809-821

Sullivan CW, Ainley DG (1987) AMERIEZ 1986: a summary of activities on board the R/V Melville and USCGC Glacier Antarctic J US 22:167-169

Sullivan CW, Cota GF, Krempin DW, Smith WO Jr (1990) Distribution and activity of bacterioplankton in the marginal ice zone of the Weddell-Scotia Sea during austral spring. Mar Ecol Prog Ser 63:239-252

Sullivan CW, McClain CR, Comiso JC, Smith WO Jr (1988) Phytoplankton standing crops within an Antarctic ice edge assessed by satellite remote sensing. J geophys Res 93:12487-12498

Zdanowski MK (1982) Distribution of saprophytic bacteria in the southern Drake Passage and in the Bransfield Strait (February-March 1981, BIOMASS-FIBEX). Polish Pol Res 3:183-191

Zdanowski MK (1985) Distribution of bacteria, organic carbon and amino acids in the southern part of Drake Passage and in Bransfield Strait during BIOMASS-SIBEX (December 1983-January 1984). Polish Pol Res 6:43-63

Zdanowski MK, Donachie SP (1993) Bacteria in the sea-ice zone between Elephant Island and the South Orkneys during the Polish sea-ice expedition, (December 1988January 1989). Polar Biol 13:245-254

Zwally HJ, Comiso JC, Parkison CL, Campbell WJ, Carsey FD, Gloersen P (1983) Antarctic sea ice, 1973-1976: satellite passive-microwave observations. NASA SP-459. US Government Printing Office, Washington DC

Manuscript first received: February 2, 1994

Revised version accepted: December 27, 1994 